ANDREW HYNES SERIES: TECTONIC PROCESSES

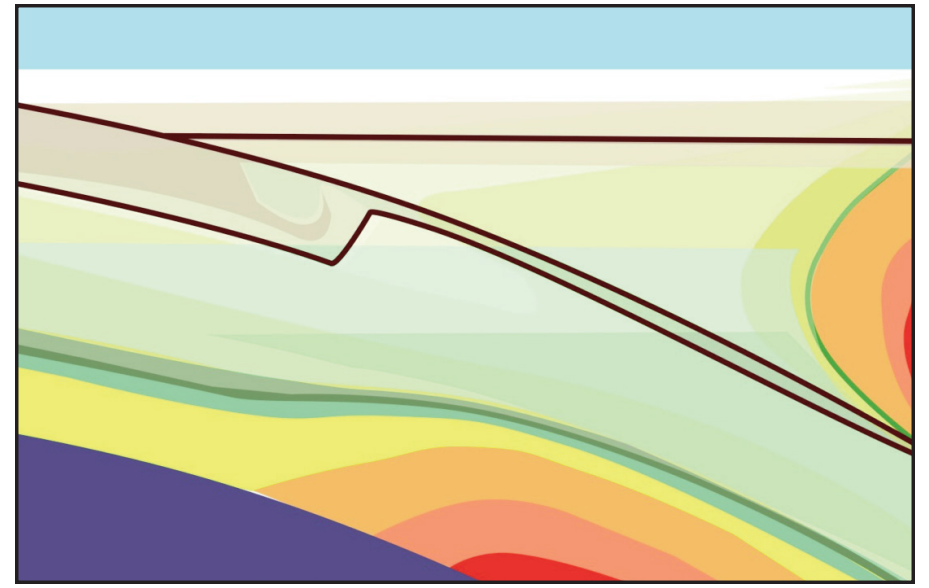

\section{Evolution of Labrador Sea-Baffin Bay: Plate or Plume Processes?}

\author{
Alexander L. Peace ${ }^{1,2}$, Gillian R. Foulger ${ }^{2}$, \\ Christian Schiffer ${ }^{2}$ and Ken J.W. McCaffrey ${ }^{2}$
}

${ }^{1}$ Department of Earth Sciences

Memorial University of Nenfoundland

St. John's, Newfoundland, Canada, A1B 3 X5

E-mail:alpeace@mun.ca

${ }^{2}$ Department of Earth Sciences

Durbam University

Durbam, United Kingdom, DH1 3LE

\section{SUMMARY}

Breakup between Greenland and Canada resulted in oceanic spreading in the Labrador Sea and Baffin Bay. These ocean basins are connected through the Davis Strait, a bathymetric high comprising primarily continental lithosphere, and the focus of the West Greenland Tertiary volcanic province. It has been suggested that a mantle plume facilitated this breakup and generated the associated magmatism. Plume-driven breakup predicts that the earliest, most extensive rifting, magmatism and initial seafloor spreading starts in the same locality, where the postulated plume impinged. Observations from the Labrador Sea-Baffin Bay area do not accord with these predictions. Thus, the plume hypothesis is not confirmed at this locality unless major ad hoc variants are accepted. A model that fits the observations better involves a thick continental lithospheric keel of orogenic origin beneath the Davis Strait that blocked the northward-propagating Labrador Sea rift resulting in locally enhanced magmatism. The Davis Strait lithosphere was thicker and more resilient to rifting because the adjacent Paleoproterozoic Nagssugtoqidian and Torngat orogenic belts contain structures unfavourably orientated with respect to the extensional stress field at the time.

\section{RÉSUMÉ}

La cassure entre le Groenland et le Canada a entrainé une expansion océanique de la mer du Labrador et de la baie de Baffin. Ces bassins océaniques sont reliés par le détroit de Davis, un haut bathymétrique constitué principalement de lithosphère continentale et de la province volcanique tertiaire de l'ouest du Groenland. Il a été suggéré qu'un panache du manteau a facilité cette cassure et généré le magmatisme associé. L'hypothèse d'une cassure produite par panache du manteau prédit que la première distension océanique, la plus importante, le magmatisme et l'expansion océanique initial se produisent là où le panache mantélique touche la croûte continentale. Or les observations dans la région de la mer du Labrador-baie de Baffin ne correspondent pas à ces prédictions. Et donc l'hypothèse du panache ne fonctionne pas dans cette région à moins que des facteurs ad hoc déterminants ne soient présents. Un modèle qui correspond mieux aux observations présuppose la présence d'une épaisse quille lithosphérique continentale d'origine orogénique sous le détroit de Davis qui aurait bloqué l'expansion océanique de la mer du Labrador vers le nord, ce qui aurait provoqué une augmentation du magmatisme localement. La lithosphère du détroit de Davis était plus épaisse et plus résistante à l'expansion océanique parce que les bandes orogéniques paléoprotérozoïques du Nagssugtoqidian et de Torngat renferment des structures défavorablement orientées par rapport au champ de contraintes d'extensions de l'époque.

Traduit par le Traducteur

\section{INTRODUCTION}

Although many continental rifts and passive margins are magma-rich (Skogseid 2001; Geoffroy 2005; Thybo and Artemieva 2013; Geoffroy et al. 2015), such as the Norwegian margin (e.g. Gernigon et al. 2015), others are relatively magmapoor (Boillot and Froitzheim 2001; Wilson et al. 2001), such as the Newfoundland margin (e.g. Eddy et al. 2017). This has led to polarization of proposed causal mechanisms into views of magma-rich or 'active' rifts (postulated to be driven by deep 


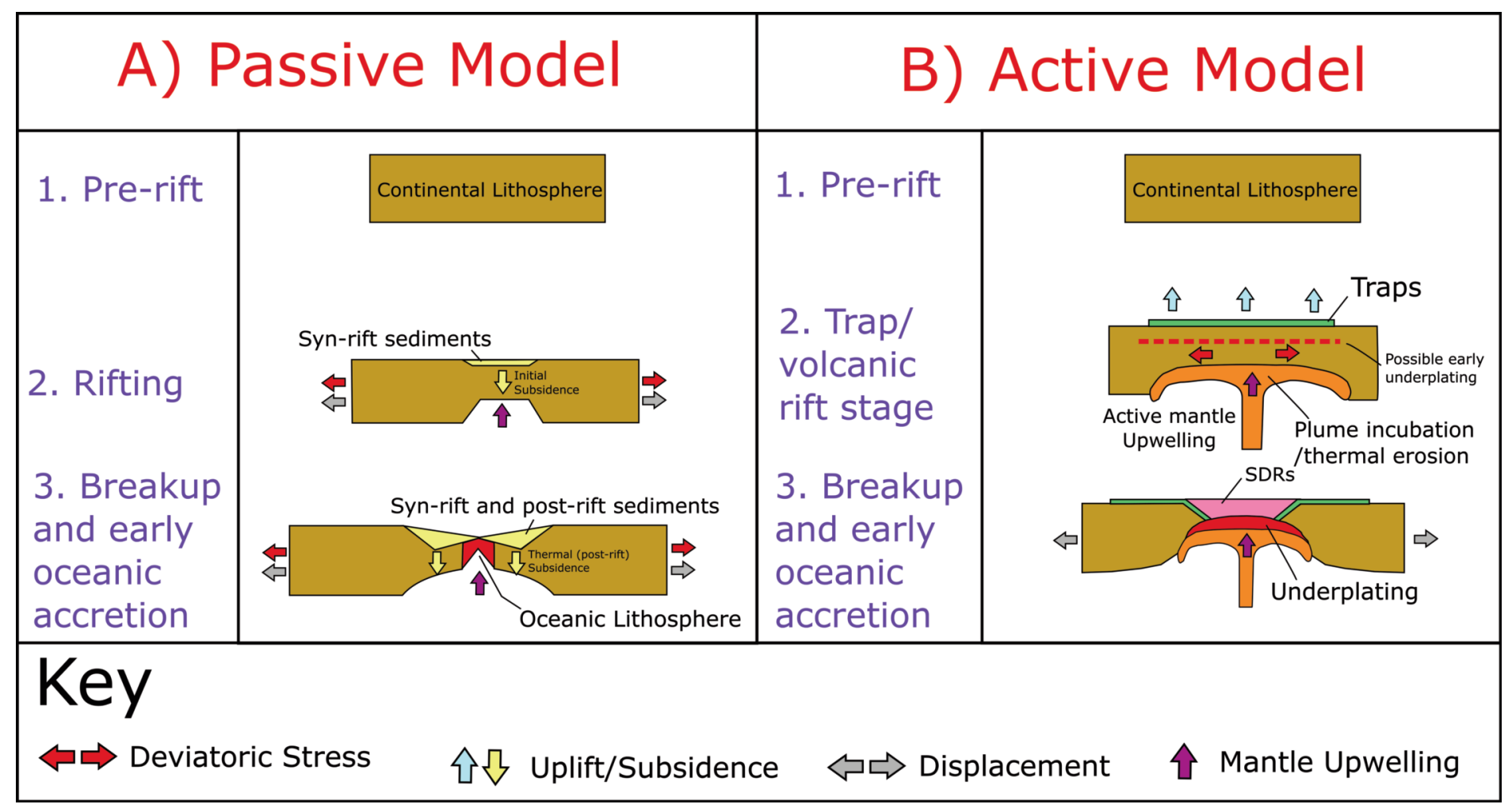

Figure 1. Comparison of A) the passive and B) active models of rifting and breakup. Modified from Geoffroy (2005) based on the concepts of Sengör and Burke (1978) and McKenzie (1978). SDRs = seaward-dipping reflectors (e.g. Mutter 1985; Paton et al. 2017; Buck 2017).

mantle plumes, e.g. Morgan 1971; Sengör and Burke 1978), and magma-poor or 'passive' rifts (postulated to be driven by stretching of the lithosphere by far-field plate forces, e.g. McKenzie 1978; Fig. 1). However, magmatism occurs even on margins categorized as 'non-volcanic' or 'magma poor' (e.g. the U-reflector offshore Newfoundland; Deemer et al. 2010; Peace et al. 2017a) because magmatism to some extent invariably accompanies continental breakup (White 1992). This suggests that 'magma-rich' and 'magma-poor' margins are extremes that represent end-members only in a continuous spectrum (Geoffroy 2005; Franke 2013). For this reason the role of the mantle and its relationship with magmatism during continental breakup remains a subject of debate (e.g. Anderson 2000; van Wijk et al. 2001; Foulger 2002; Campbell 2007; Calvès et al. 2008; Foulger et al. 2015; Shellnutt et al. 2017). Furthermore, an unequivocal detection of a Morgan-type mantle plume (i.e. a thermal rising from the deep lower mantle) has yet to be made, using either geochemical or geophysical tools (Hwang et al. 2011; Foulger et al. 2013; Lustrino and Anderson 2015).

In this contribution we discuss, using observations from West Greenland and northeastern Canada, the predictions of the mantle plume hypothesis as the mechanism facilitating continental breakup and magmatism (Gill et al. 1992; Gerlings et al. 2009). We find that few of the predictions are confirmed. We suggest that breakup was, instead, predominantly driven by plate tectonic processes and that lithospheric structure in the neighbourhood of the Davis Strait was responsible for the excess Tertiary magmatism there that has traditionally been interpreted as the product of a mantle plume.

\section{CONTINENTAL BREAKUP AND MAGMATISM BETWEEN GREENLAND AND CANADA}

The Labrador Sea and Baffin Bay (Fig. 2) opened as a result of divergent motion between Greenland and Canada (Srivastava 1978; Chalmers and Pulvertaft 2001; Abdelmalak et al. 2012; Hosseinpour et al. 2013; Delescluse et al. 2015; Alsulami et al. 2015; Peace et al. 2016). This separation occurred in three stages (Oakey and Chalmers 2012): 1) Paleocene separation between North America and Greenland while the latter was still attached to Eurasia, 2) continued Eocene separation between Greenland and North America as separation between Eurasia and Greenland (Greenland moving as an independent plate) began, and 3) since the Oligocene continued separation between Eurasia and Greenland, which again was attached to North America. Extension between Greenland and Canada resulted in oceanic spreading in the Labrador Sea (Chalmers and Laursen 1995) and most likely in Baffin Bay (Suckro et al. 2012) but not at the Davis Strait (Funck et al. 2012).

The earliest rifting, (possibly Triassic; Larsen et al. 2009) and the oldest and most extensive oceanic crust in the Labrador Sea-Baffin Bay area, occurs in the southern Labrador Sea (mid-Paleocene; Srivastava 1978; Chalmers and Pulvertaft 2001). The spatial and temporal extent of oceanic crust in Baffin Bay (Suckro et al. 2012) is less than in the Labrador Sea (Srivastava 1978). The Davis Strait is a bathymetric high linking the Labrador Sea to Baffin Bay and it is primarily underlain by continental lithosphere (Dalhoff et al. 2006) up to $20 \mathrm{~km}$ thick (Funck et al. 2012). The Ungava Transform Fault System (Suckro et al. 2013), a 'leaky' transform system 


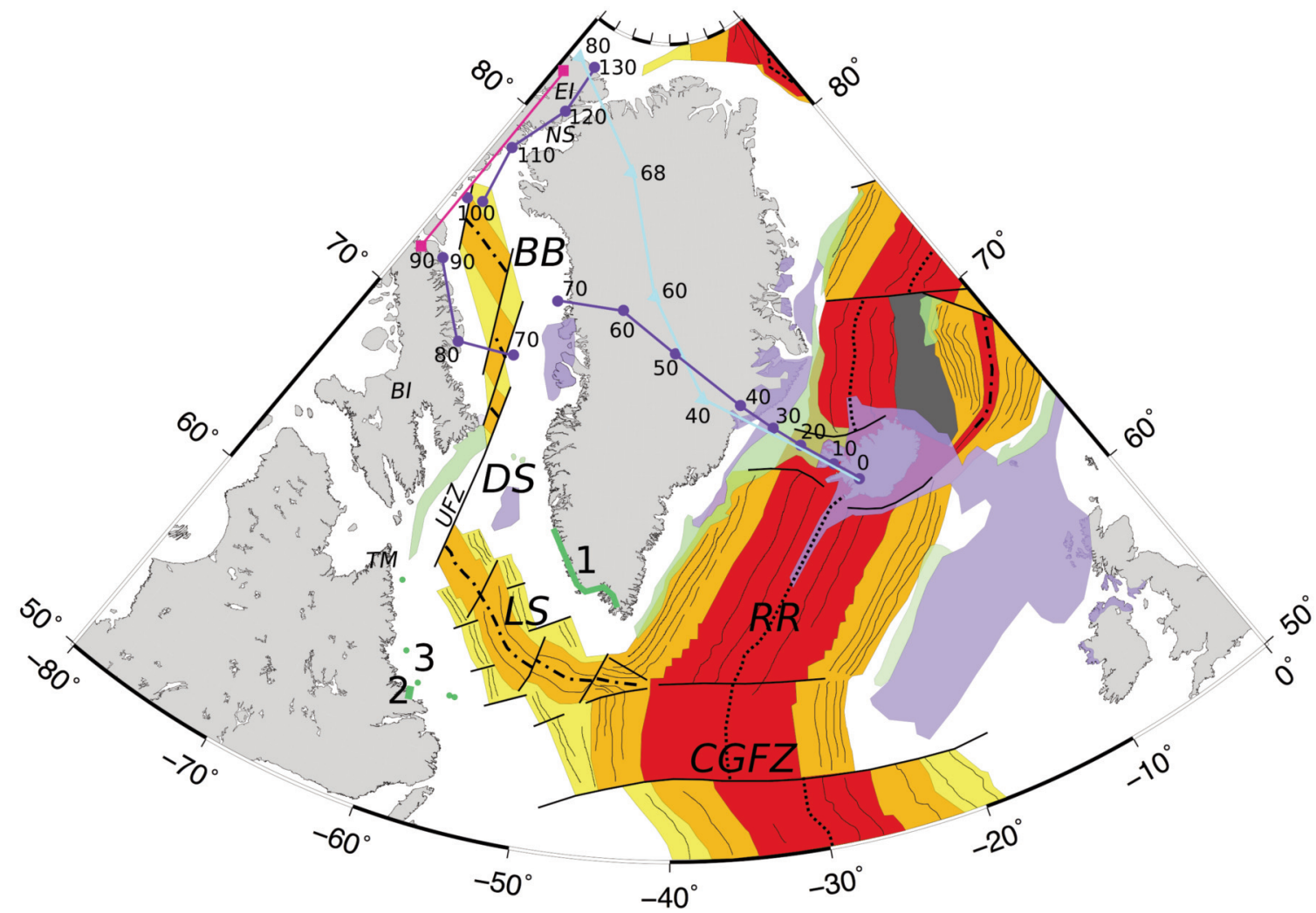

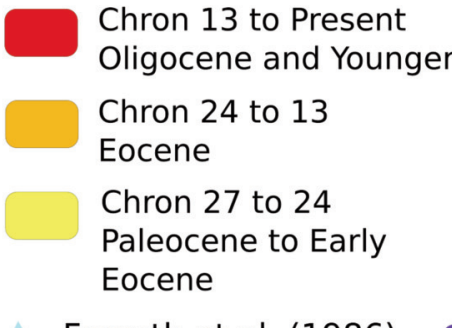

Forsyth et al. (1986)

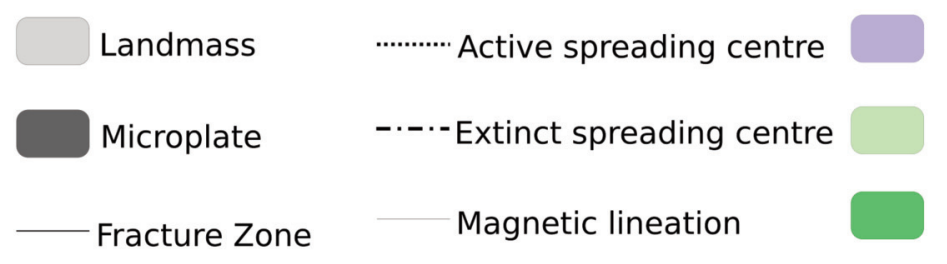

Paleogene magmatism

Seaward dipping Reflectors (SDRs)

Cretaceous magmatism

\section{Major dyke swarm \\ 2. Possible nephelinite dykes \\ 3. Basalts in offshore wells}

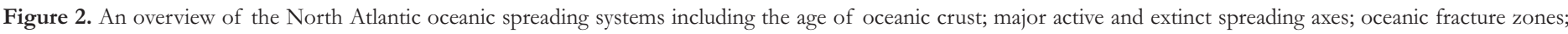

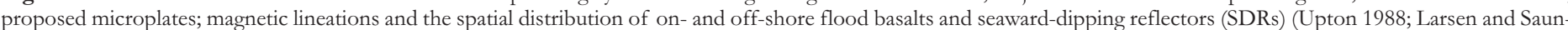

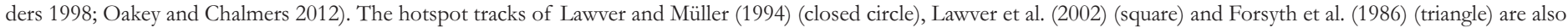

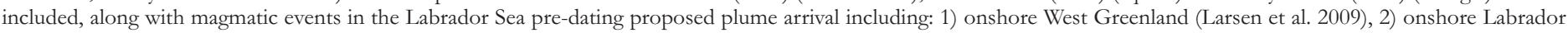

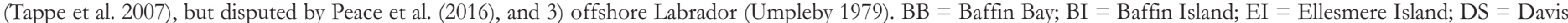

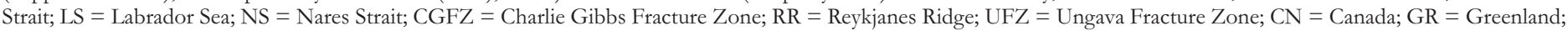
$\mathrm{IL}=$ Iceland; UK = United Kingdom; IR = Ireland.

where small amounts of oceanic crust may have been produced in the absence of fully developed oceanic spreading (Funck et al. 2012), traverses the Davis Strait.

The earliest magmatism related to the opening of the Labrador Sea is possibly Late Triassic in age (ca. $220 \mathrm{Ma}$; Larsen et al. 2009). However, it is not until the Early Cretaceous that a strong extensional stress field is evidenced by the intrusion of coast-parallel dykes in West Greenland (ca. 150 Ma; Larsen et al. 2009) and possibly some debated equivalent dykes in Labrador (Tappe et al. 2007; Peace et al. 2016) along with a Mesozoic diatreme (King and McMillan 1975; Wilton et al. 2002; Wilton et al. 2016). Breakup occurred in the Paleocene (Chalmers et al. 1995), in addition to the eruption of flood basalt around the Davis Strait as four region-wide formations: the 62.5-61 Ma Vaigat Formation picrite, the 61-60 Ma Maligât Formation depleted basalt (also in the Hellefisk-1 offshore well), the 60-58 Ma Svartenhuk Formation lessdepleted basalt and the Naqerloq Formation 56-54 Ma enriched basalt (Larsen et al. 2016). Furthermore, two less widespread basalt sequences include the 53.5 Ma Erqua Formation alkali basalt and the $38.7 \mathrm{Ma}$ Talerua Member transitional basalt (Larsen et al. 2016). 


\section{THE MANTLE PLUME HYPOTHESIS AND BREAKUP BETWEEN GREENLAND AND CANADA}

A mantle plume (Morgan 1971) has been proposed as the causal mechanism for continental breakup and magmatism between Greenland and Canada (e.g. Storey et al. 1998; Courtillot et al. 1999; Nielsen et al. 2002; Funck et al. 2007; Gerlings et al. 2009; Altenbernd et al. 2015). It is postulated that initial rifting was relatively amagmatic (Nielsen et al. 2002; Altenbernd et al. 2015) and that the arrival of a mantle plume at ca. 62-60 Ma (Storey et al. 1998) led to the onset of seafloor spreading in the Labrador Sea (Gerlings et al. 2009) and widespread magmatism around the Davis Strait (Holm et al. 1993; Storey et al. 1998). The postulated plume is claimed to underlie Iceland presently (Tegner et al. 1998), and to have remained fixed with respect to other mantle plumes throughout its existence. This is suggested by various authors to have existed since ca. $250 \mathrm{Ma}$, depending on what basalt units are considered to comprise its associated 'plume-head' volcanic rocks (e.g. Lawver and Müller 1994). Figure 2 depicts three postulated plume tracks that are commonly cited as explanations for breakup and magmatism in West Greenland (Forsyth et al. 1986; Lawver and Müller 1994; Lawver et al. 2002). In this paper we primarily discuss the Lawver and Müller (1994) plume track as this is most complete and the one that approaches most closely the Davis Strait.

Observations in the Labrador Sea-Baffin Bay rift system that have been attributed to a mantle plume include:

1. The onset of seafloor spreading in the Labrador Sea (Gerlings et al. 2009);

2. Movement on the Ungava fault system (Storey et al. 1998);

3. Volcanism in West Greenland and Baffin Island (Chalmers et al. 1995; Larsen et al. 2016);

4. Interpreted underplating beneath the Davis Strait (Gerlings et al. 2009);

5. High ${ }^{3} \mathrm{He} /{ }^{4} \mathrm{He}$ (Graham et al. 1998; Dale et al. 2009);

6. Regional uplift patterns (Dam et al. 1998; Japsen et al. 2006); and

7. High melting temperatures estimated for picrite cumulates (Gill et al. 1992).

Despite this there are first-order disparities between the predictions of the mantle plume model and regional observations (Nielsen et al. 2007; McGregor et al. 2014; Peace et al. 2014). The mantle plume hypothesis requires that the earliest and most extensive uplift, magmatism and rifting occurred closest to the plume centre (e.g. Franke 2013; Fig. 3). However, this did not occur in the Labrador Sea-Baffin Bay rift system if the plume track of Lawver and Müller (1994) is assumed, as exemplified by the following:

1. Seafloor spreading started in the southern Labrador Sea before the north (Roest and Srivastava 1989);

2. Seafloor spreading was delayed and developed poorly in Baffin Bay (Suckro et al. 2012);

3. Seafloor spreading did not develop at all in the Davis Strait (Suckro et al. 2013), the location of the plume centre predicted by Lawver and Müller (1994); and
4. The predicted kilometre-scale uplift at the centre of the arriving plume did not occur (Redfield 2010; McGregor et al. 2013).

These points are discussed in more detail in the following subsections.

\section{The Labrador Sea}

The Labrador Sea progressively opened from south to north (Oakey and Chalmers 2012; Delescluse et al. 2015), and although there is a consensus that spreading started no later than Chron 27 (Paleocene; Chalmers and Laursen 1995; Oakey and Chalmers 2012) some work suggests that spreading may have started as early as Chron 33 (Roest and Srivastava 1989; Srivastava and Roest 1999). Despite this debate it is clear that seafloor spreading started in the southern Labrador Sea considerably before the north (Roest and Srivastava 1989). This does not fit a model whereby a plume located to the north (Lawver and Müller 1994) initiated seafloor spreading (Storey et al. 1998; Gerlings et al. 2009). If seafloor spreading was initiated by mantle plume arrival it would be expected to start nearest to the plume and to propagate away from it (Fig. 3).

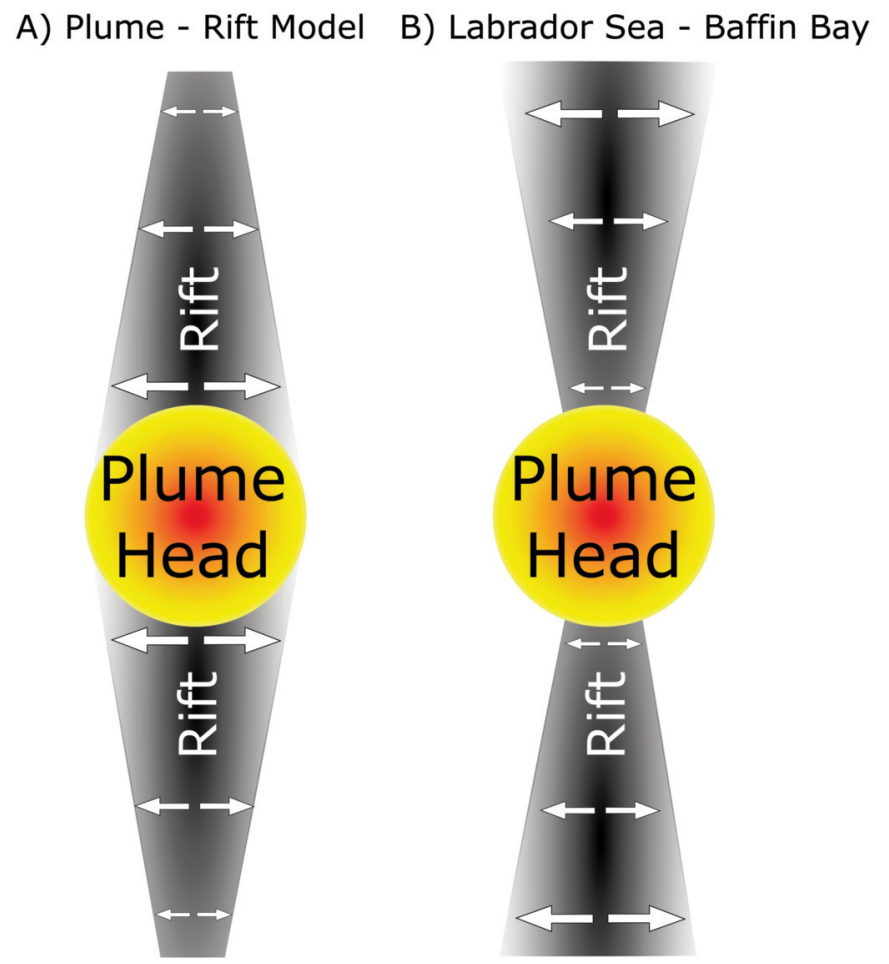

Figure 3. Arrows show A) predictions of rifting in response to a rising thermal anomaly in the mantle and B) observations in the Labrador Sea-Baffin Bay rift system. Modified from Franke (2013) whereby the original figure showed a similar example from the South Atlantic where observations of rifting and breakup again do not appear to fit the predictions of the mantle plume hypothesis.

\section{Baffin Bay}

The nature of seafloor spreading in Baffin Bay is contrary to plume hypothesis predictions. First, it has been proposed that Baffin Bay is either entirely underlain by continental crust 
(Kerr 1967; Van der Linden 1975) or that if oceanic crust is present it is less extensive than in the Labrador Sea (Jackson et al. 1979; Gerlings et al. 2009; Suckro et al. 2012; Hosseinpour et al. 2013). Baffin Bay is proposed to have been much closer to the plume (Lawver and Müller 1994) and so the reverse would be expected.

\section{The Davis Strait}

In the Davis Strait seafloor spreading was never fully initiated as it was in the Labrador Sea (Srivastava 1978) and probably Baffin Bay (Suckro et al. 2012). Instead, a 'leaky transform' system developed (Funck et al. 2007). It is again not clear why a mantle plume should cause seafloor spreading in the Labrador Sea to the south (Storey et al. 1998; Gerlings et al. 2009) but not in the much closer Davis Strait. The Davis Strait is the focus of the West Greenland Tertiary volcanic province (Fig. 2; Storey et al. 1998; Gerlings et al. 2009; Larsen et al. 2016) and, although volcanic rocks are observed on Baffin Island (Clarke and Upton 1971; Geoffroy et al. 2001), rift-related dykes are also documented to the south on the margins of the Labrador Sea (Larsen et al. 2009). This disparity between a predicted time-progressive volcanic track as a result of plume passage (Lawver and Müller 1994) and the observations provides further evidence against a fixed mantle plume as the primary cause of the magmatism.

\section{Vertical Motion Studies}

Low-temperature thermochronological studies (e.g. apatite fission track dating (AFT), helium isotopes and vitrinite reflectance) may be used to date vertical motions including possible plume-related exhumation. Results from West Greenland linking apparent uplift to presumed plume activity (Japsen et al. 2006) are controversial (Redfield 2010). Furthermore, results from Baffin Island suggest a slow and long-lived exhumation since the Late Proterozoic while Cenozoic uplift is not detected (Yaehne 2008; McGregor et al. 2013; Creason 2015). The Torngat Mountains in Labrador experienced rapid uplift in the latest Jurassic-earliest Cretaceous, but this is inferred to be rift-flank uplift (Centeno 2005). AFT ages from Ellesmere Island and along the Nares Strait show peaks in the Paleogene and Permo-Triassic, reflecting the complex tectonic evolution of the region (Arne et al. 2002; Grist and Zentilli 2005; Hansen et al. 2011). However, this is not when the postulated plume is predicted to have underlain the area (approx. 120-90 $\mathrm{Ma}$ ). Apparent vertical motions along the West GreenlandEast Canada margin are thus not consistent with the spatial and temporal pattern of vertical motions predicted for plume head impingement and a migrating plume tail.

\section{Plume Variants}

Several variants of the plume hypothesis have been proposed to account for the mismatches between predictions and observations by Gill et al. (1992). These include: 1) a 'doughnutshaped' plume; 2 ) a shift in relative plume position (migrating plume); 3) multiple, separate plumes; and 4) a non-axisymmetric plume head. Numerical modelling of the South Atlantic has been used to support the suggestion that plume-driven rift ini- tiation may be offset from the proposed plume impingement location (Beniest et al. 2017), and that mantle contamination in combination with elevated temperatures near Iceland may explain igneous crustal thickness (Shorttle et al. 2014), concepts that may be applicable in the Labrador Sea-Baffin Bay area. Variants of the standard plume model are, however, not useful unless they make predictions of their own that can be tested - arbitrary ad hoc adjustments introduced merely to explain a posteriori observations that do not fit the simple model do not progress understanding of causative processes. It is clear that non-plume mechanisms for the Labrador Sea-Davis Strait-Baffin Bay region must be considered.

\section{THE ROLE OF LITHOSPHERIC STRUCTURE AND PROCESSES IN THE TECTONO-MAGMATIC EVOLUTION}

Plate-related mechanisms provide candidate mechanisms for breakup and magmatism between Greenland and Canada (Foulger 2002; Nielsen et al. 2007; Peace et al. 2014; Foulger et al. 2015). In this section we discuss the role of lithospheric architecture in controlling breakup and associated magmatism between Greenland and Canada.

Beneath the Davis Strait (Fig. 2) the crust (Fig. 4 and 5A) is thicker than elsewhere in the Baffin Bay-Labrador Sea rift system (Laske et al. 2012; Welford and Hall 2013). According to a model of the depth of the lithosphere-asthenosphere boundary (LAB) (Schaeffer and Lebedev 2015; Schiffer et al. 2017; Lebedev et al. 2017) the lithosphere is also thicker (Fig. 5B). According to this LAB model the Davis Strait may be underlain by lithosphere ca. $150 \mathrm{~km}$ thick compared to the Labrador Sea and Baffin Bay which may have lithosphere as thin as ca. $50 \mathrm{~km}$ (Fig. 5).

Local mantle convection patterns may have been influenced by a lithospheric keel protruding into the asthenosphere (Fig. 6). Regions of thick lithosphere have been inferred to influence asthenospheric flow elsewhere, e.g. in southeast Brazil (Assumpção et al. 2006). Such structures may induce lateral thermal gradients leading to initiation of small-scale convection cells that boost adiabatic melting (Simon et al. 2009; Ballmer et al. 2010). Lateral temperature gradients beneath the Davis Strait may have varied, both spatially and temporally, because of variable crustal and lithospheric thinning (Suckro et al. 2013). Such lateral temperature gradients are expected particularly if small amounts of oceanic crust were produced along 'leaky' transform faults (Funck et al. 2007).

Thicker Davis Strait lithosphere (Fig. 5) could have had an insulating effect, causing large asthenosphere temperature gradients from north (Baffin Bay) to south (Labrador Sea) (Lenardic et al. 2005; Whittington et al. 2009; Heron and Lowman 2011) and therefore enhancing melting caused by other mechanisms such as edge-driven convection (e.g. Ghods 2002; van Wijk et al. 2008; Simon et al. 2009). Continental lithosphere persisted in the Davis Strait longer than elsewhere (Srivastava and Roest 1999). The Davis Strait is a considerably smaller region than others where insulation by continental lithosphere has been inferred to be influential, e.g. supercontinents (Lenardic et al. 2011), so this is likely to have been a minor effect. 
A) Profile 1

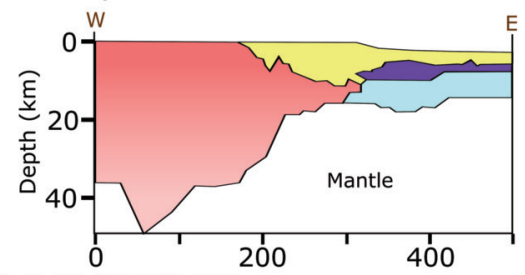

C) $A W I-20100400$
B) Profile 2

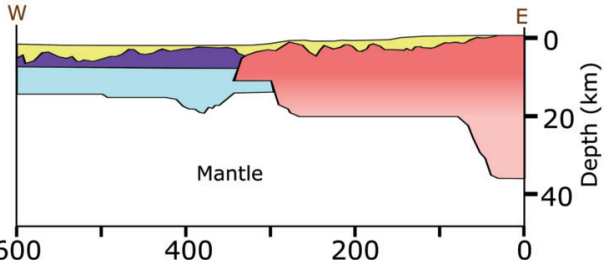

D) 901

E) 903

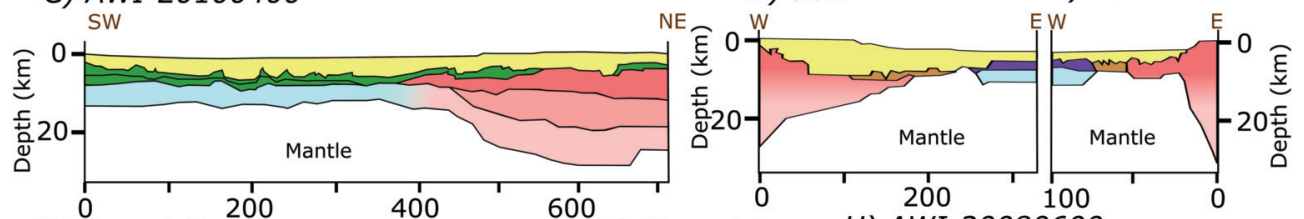

G) Nugget 1

F) Nugget 2

EN $\mathrm{S} N \mathrm{NW}$

H) $A W I-20080600$

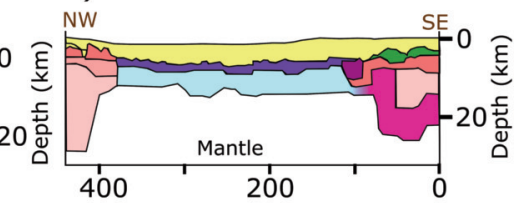

$\mathrm{km}$

Key for profiles (A-H)

Sediments

Sediments \& igneous rocks

Igneous rocks

Transform deformation

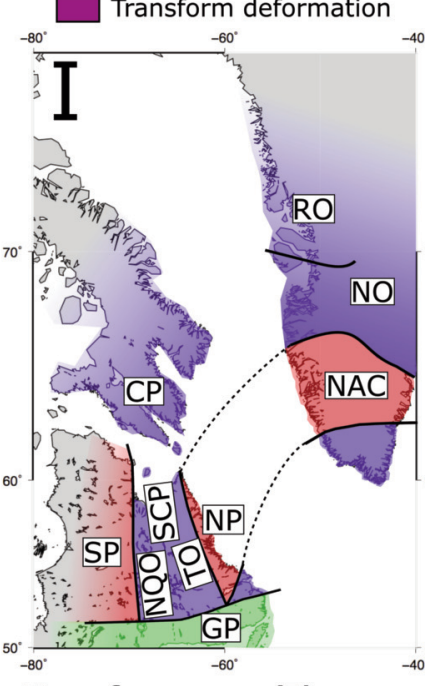

Key for map (I)

$1.5-1 \mathrm{Ga}$

2.3-1.7 Ga

$>2.5 \mathrm{Ga}$

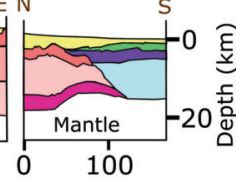

per Crust

Middle Crust

Lower Crust

Underplating/HVLC

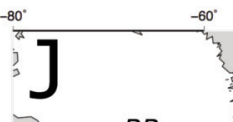

$B B$
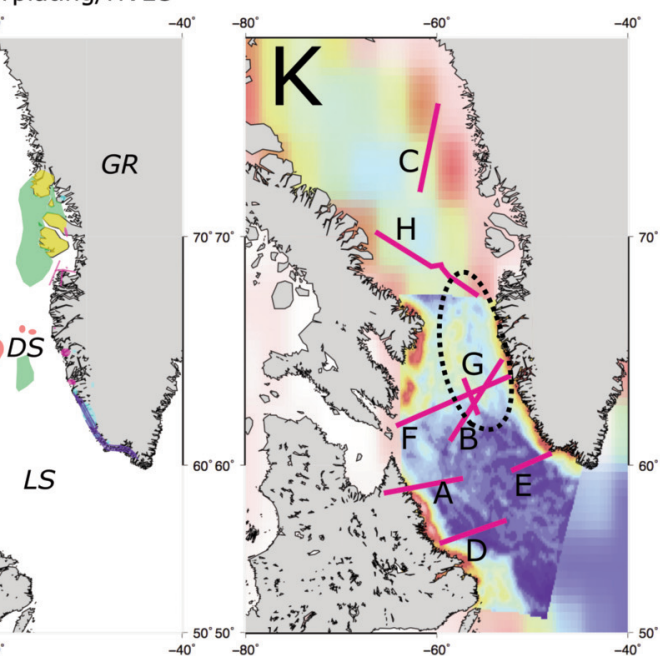

Key for map (J)

Offshore Basalt

Seaward Dipping Reflectors Onshore Tertiary Basalt

Jurassic \& Triassic Intrusions

Paleogene Intrusions

Cretaceous Intrusions

Key for map (K)

Profiles (A-H)

Landmass

:...:Possible extent of underplating

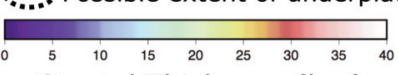

Crustal Thickness (km)

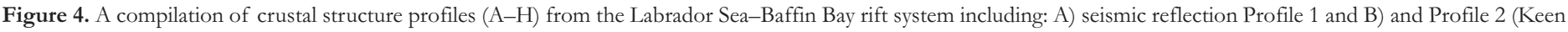

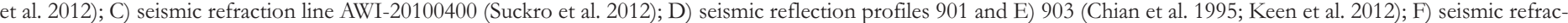

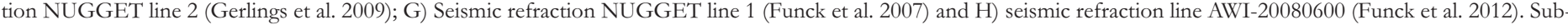

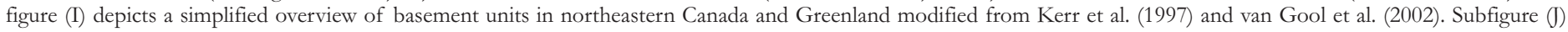

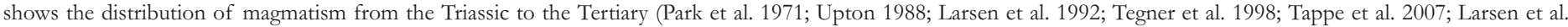

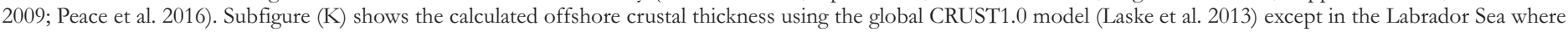

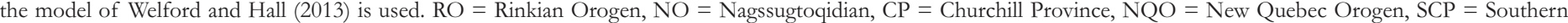

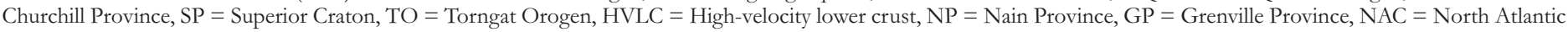
Craton, BB = Baffin Bay, DS = Davis Strait, LS = Labrador Sea, GR = Greenland, BI = Baffin Island and LA = Labrador. 

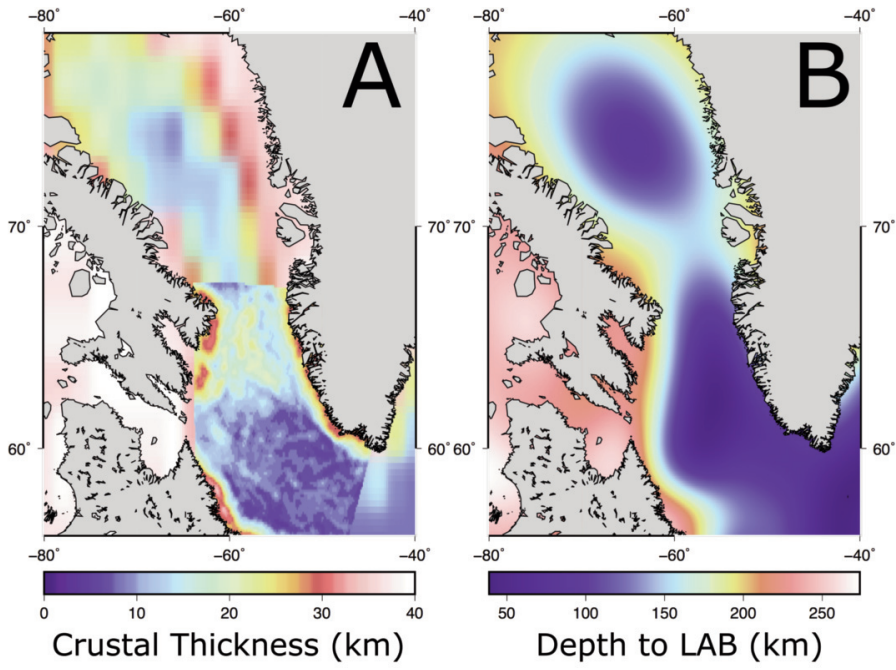

Figure 5. A) Calculated offshore crustal thickness using the global CRUST1.0 model (Laske et al. 2013) except in the Labrador Sea where the Welford and Hall (2013) grid is used. B) Depth to the lithosphere-asthenosphere boundary (LAB) using multimode waveform tomography (Schaeffer and Lebedev 2015; Schiffer et al. 2017).

The thickness of the pre-rift continental crust has also been shown to be capable of exerting a significant influence on thinning and magmatic evolution during rifting and continental breakup (Audet and Bürgmann 2011; Petersen and Schiffer 2016). Previous work has shown that thick, warm, weak initial crust promotes dislocated extension and continental, pre-breakup melting whereas extension of thinner, colder, more brittle crust tends to be more localized, leading to quicker continental breakup in the absence of pre-breakup melting (Petersen and Schiffer 2016). The predictions of this model appear to be supported by observations of rifting in the Davis Strait as well as its location as the focus of the West Greenland Tertiary volcanic province.

The most important factor that boosted melt production at the Davis Strait region is probably the role the region played as a barrier to the propagating rift (Koopmann et al. 2014). Recent modelling suggests that such structural barriers retard rifting and enhance local melt production by restricting the area over which it can escape (Koopmann et al. 2014). Systematic variations in the abundance of magmatism are reported along the margins of the North and South Atlantic (Chalmers 1997; Franke et al. 2007; Skaarup et al. 2006; Elliott and Parson 2008; Blaich et al. 2009; Koopmann et al. 2016) with more abundant magmatism near 'transfer zones,' interpreted to have comprised barriers to rift propagation (Koopmann et al. 2014).

Numerical modelling shows that stress concentrations that encourage adiabatic melting can occur at ridge-transform intersections (Beutel 2005). This effect may explain instances of excess volcanism where ridge segments terminate at transform faults (Beutel 2005). Examples of volcanism produced in such a tectonic environment include the Foundation Seamounts (Hekinian et al. 1999), the Amsterdam and St. Paul Islands (Graham et al. 1999) and the Galapagos Islands. Two such ridge-transform intersections occur in the Davis Strait (Suckro et al. 2013), where two spreading centres terminate

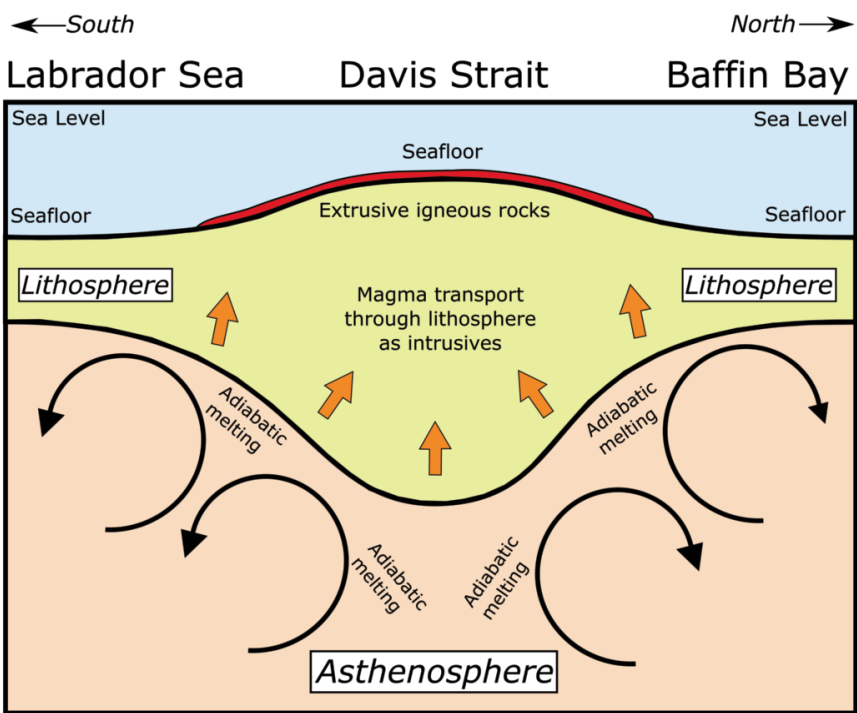

Figure 6. Schematic depiction of the model proposed herein. In this model the thicker crust and lithosphere in the Davis Strait, compared to the Labrador Sea and Baffin Bay (Fig. 5) where extensive thinning took place, could have induced smallscale convection (e.g. Simon et al. 2009). Small-scale convection in proximity to the Davis Strait could have resulted in adiabatic melting leading to the widespread magmatic rocks focused in this area. The reason lithospheric thinning in the Davis Strait was less than the Labrador Sea may have been due to the presence of pre-existing orogenic terranes that proved particularly resistant to thinning (Fig. 4I).

and melt produced will have found ready pathways to the surface through the transtensional segments.

Overall, a thicker continental lithosphere may have been conducive to enhanced melt production for a number of reasons including: 1) influencing asthenospheric flow; 2) providing additional insulation and thus enhancing other mechanisms; 3) comprising a barrier to rift propagation that was conducive to melt generation, 4) necessitating the development of a transform fault against which melt accumulated, increasing the magmatic volume locally, and 5) promoting dislocation extension with associated volcanism rather than abrupt breakup. Several crust and lithosphere-related effects thus predisposed the Davis Strait region to enhanced magmatism. The unusual magmatism there, traditionally attributed to mantle plume activity, may thus be explained by the interaction of a propagating rift and pre-existing lithosphere architecture.

\section{Preservation of Thicker Continental-type Crust and Lithosphere in the Davis Strait}

Integral to the mechanisms we propose is the persistence of lithosphere near the Davis Strait that is thicker than Baffin Bay and the Labrador Sea. However, whether the crust and lithosphere in the Davis Strait and slightly farther north (Fig. 5) was thicker than the surrounding areas prior to rifting or only after preferential thinning in the Labrador Sea and Baffin Bay areas is relevant because this affects the feasibility of the mechanisms discussed above. The potential contribution of underplating (Gerlings et al. 2009) is also relevant.

The Davis Strait lies adjacent to the Paleoproterozoic Nagssugtoqidian (Connelly and Mengel 2000; van Gool et al. 2002; Kolb 2014; Engström and Klint 2014) and Torngat 
(Funck and Louden 1999; Funck et al. 2000) orogenic belts (Fig. 4I) and thus the crust and lithosphere were almost certainly thickened prior to Mesozoic rifting. This suggests that the thick lithospheric keel we postulate was long-established prior to the onset of rifting.

Major structures in those terranes (Wilson et al. 2006) lay approximately perpendicular to the rift axis (e.g. Srivastava and Keen 1995; Abdelmalak et al. 2012) and may have thus resisted northward rift propagation (Fig. 4I) resulting in the reactivation of structures oblique to the extension direction (Peace et al. 2017b). The unfavourable orientation of pre-existing terranes may explain the failure of complete continental breakup locally between Greenland and Canada and have encouraged the transfer of opening to the Northeast Atlantic between Greenland and Eurasia. That rifting exploited more favourable Caledonian structures to the east of Greenland (Doré et al. 1997; Schiffer et al. 2015a, b, in press; Mjelde et al. 2016).

The large-scale geometry of the Labrador Sea-Baffin Bay rift system, that is a right-lateral step through the Davis Strait, may be a direct consequence of the presence of the Paleoproterozoic Nagssugtoqidian and Torngat orogens. This right-lateral step in the plate boundary geometry would have resulted in compression in the Davis Strait (Chalmers et al. 1993; Gregersen and Bidstrup 2008; Peace et al. 2017b) during later stages when Greenland moved north (magnetic Chron 24-13; Abdelmalak et al. 2012; Oakey and Chalmers 2012). This in turn would have allowed continued extension in the Labrador Sea and (probably) Baffin Bay but minimal thinning in the Davis Strait where transform tectonics continued to dominate.

Overall, the preservation of thicker continental-type crust and lithosphere in the Davis Strait is likely a combination of: 1) initial excess thickness, and 2) rifting not manifesting there as a result of the pre-existing orogenic belts that hindered rift propagation.

\section{CONCLUDING REMARKS}

A suite of observations in the Labrador Sea-Baffin Bay rift system related to the geometry, spatial and temporal extent of rifting, seafloor spreading, rift-related magmatism and uplift do not fit the predictions of a model of breakup in response to the arrival of a mantle plume. This conclusion accords with the suggestion by Alsulami et al. (2015) that the role of a mantle plume has been overstated and that of Armitage et al. $(2009,2010)$ that elevated mantle temperatures alone cannot explain North Atlantic magmatism and rifting without the inheritance of previous structures.

The history of rifting, magmatism and seafloor spreading in the region are consistent with reaction to changing far-field stresses associated with plate tectonics. The observations can be explained without invoking a mantle plume. Tertiary volcanism in the Davis Strait results from local lithospheric structure. A thick lithospheric keel enhanced convection and comprised a barrier to the northerly propagating Labrador Sea rift, resulting in enhanced magmatism. This lithospheric keel is likely related to large-scale, pre-existing structures associated with the Paleoproterozoic Nagssugtoqidian and Torngat orogens. Pre-existing orogenic belts in the disintegrating continen- tal lithosphere had first-order influences on the large-scale mode, timing and geometry of breakup across the entire North Atlantic region.

\section{ACKNOWLEDGEMENTS}

We would like to thank the handling editor Brendan Murphy and the two anonymous reviewers for their input which greatly improved this article. Alexander Peace's postdoctoral fellowship at Memorial University is funded by the Hibernia Project Geophysics Support Fund. Christian Schiffer's postdoctoral fellowship at Durham University is funded by the Carlsberg Foundation. We thank the North Atlantic research group for valuable inspiration during the 2016 and 2017 North Atlantic workshops at Durham University.

\section{REFERENCES}

Abdelmalak, M.M., Geoffroy, L., Angelier, J., Bonin, B., Callot, J.P., Gélard, J.P., and Aubourg, C., 2012, Stress fields acting during lithosphere breakup above a melting mantle: A case example in West Greenland: Tectonophysics, v. 581, p. 132 143, https://doi.org/10.1016/j.tecto.2011.11.020.

Alsulami, S., Paton, D.A., and Cornwell, D.G., 2015, Tectonic variation and structural evolution of the West Greenland continental margin: AAPG Bulletin, v. 99, p. 1689-1711, https://doi.org/10.1306/03021514023.

Altenbernd, T., Jokat, W., Heyde, I., and Damm, V., 2015, Geophysical evidence for the extent of crustal types and the type of margin along a profile in the northeastern Baffin Bay: Journal of Geophysical Research, v. 120, p. 7337-7360, https:doi.org/10.1002/2015JB012307.

Anderson, D.L., 2000, The thermal state of the upper mantle; No role for mantle plumes: Geophysical Research Letters, v. 27, p. 3623-3626, https://doi.org/ 10.1029/2000GL011533.

Armitage, J.J., Henstock, T.J., Minshull, T.A., and Hopper, J.R., 2009, Lithospheric controls on melt production during continental breakup at slow rates of extension: Application to the North Atlantic: Geochemistry, Geophysics, Geosystems, v. 10, Q06018, https://doi.org/10.1029/2009GC002404.

Armitage, J.J., Collier, J.S., and Minshull, T.A., 2010, The importance of rift history for volcanic margin formation: Nature, v. 465, p. 913-917, https://doi.org/ 10.1038 / nature09063.

Arne, D.C., Grist, A.M., Zentilli, M., Collins, M., Embry, A., and Gentzis, T., 2002, Cooling of the Sverdrup Basin during Tertiary basin inversion: Implications for hydrocarbon exploration: Basin Research, v. 14, p. 183-205, https://doi.org/ 10.1046/j.1365-2117.2002.00163.x.

Assumpção, M., Heintz, M., Vauchez, A., and Silva, M.E., 2006, Upper mantle anisotropy in SE and Central Brazil from SKS splitting: Evidence of asthenospheric flow around a cratonic keel: Earth and Planetary Science Letters, v. 250, p. 224-240, https://doi.org/10.1016/j.epsl.2006.07.038.

Audet, P., and Bürgmann, R., 2011, Dominant role of tectonic inheritance in supercontinent cycles: Nature Geoscience, v. 4, p. 184-187, https://doi.org/ 10.1038/ngeo1080.

Ballmer, M.D., Ito, G., van Hunen, J., and Tackley, P.J., 2010, Small-scale sublithospheric convection reconciles geochemistry and geochronology of 'Superplume' volcanism in the western and south Pacific: Earth and Planetary Science Letters, v. 290, p. 224-232, https://doi.org/10.1016/j.epsl.2009.12.025.

Beniest, A., Koptev, A., and Burov, E., 2017, Numerical models for continental break-up: Implications for the South Atlantic: Earth and Planetary Science Letters, v. 461, p. 176-189, https://doi.org/10.1016/j.epsl.2016.12.034.

Beutel, E.K., 2005, Stress-induced seamount formation at ridge-transform intersections, in Foulger, G.R., Natland, J.H., Presnall, D.C., and Anderson, D.L., eds., Plates, plumes and paradigms: Geological Society of America Special Papers, v. 388, p. 581-593, https://dx.doi.org/10.1130/0-8137-2388-4.581

Blaich, O.A., Faleide, J.I., Tsikalas, F., Franke, D., and León, E., 2009, Crustal-scale architecture and segmentation of the Argentine margin and its conjugate off South Africa: Geophysical Journal International, v. 178, p. 85-105, https://doi.org/10.1111/j.1365-246X.2009.04171.x

Boillot, G., and Froitzheim, N., 2001, Non-volcanic rifted margins, continental break-up and the onset of sea-floor spreading: Some outstanding questions, in Wilson, R.C.L., Whitmarsh, R.B., Taylor, B., and Froitzheim, N., eds., Non-Volcanic Rifting of Continental Margins: A Comparison of Evidence from Land and Sea: Geological Society, London, Special Publications, v. 187, p. 9-30, https://doi.org/10.1144/GSL.SP.2001.187.01.02.

Buck, W.R., 2017, The role of magmatic loads and rift jumps in generating seaward dipping reflectors on volcanic rifted margins: Earth and Planetary Science Letters, v. 466, p. 62-69, https://doi.org/10.1016/j.epsl.2017.02.041.

Calvès, G., Clift, P.D., and Inam, A., 2008, Anomalous subsidence on the rifted vol- 
canic margin of Pakistan: No influence from Deccan plume: Earth and Planetary Science Letters, v. 272, p. 231-239, https://doi.org/10.1016/ j.epsl.2008.04.042.

Campbell, I.H., 2007, Testing the plume theory: Chemical Geology, v. 241, p. 153176, https://doi.org/10.1016/j.chemgeo.2007.01.024.

Centeno, J.P., 2005, Exhumation and incision history of the Torngat Mountains, northern Labrador and Quebec, Canada, using apatite (U-Th)/He thermochronology: Unpublished MSc thesis, University of Kansas, KS, 184 p.

Chalmers, J.A., 1997, The continental margin off southern Greenland: along-strike transition from an amagmatic to a volcanic margin: Journal of the Geological Society, v. 154, p. 571-576, https://doi.org/10.1144/gsigs.154.3.0571.

Chalmers, J.A., and Laursen, K.H., 1995, Labrador Sea: the extent of continental and oceanic crust and the timing of the onset of seafloor spreading: Marine and Petroleum Geology, v. 12, p. 205-217, https://doi.org/10.1016/02648172(95)92840-S.

Chalmers, J.A., and Pulvertaft, T.C.R., 2001, Development of the continental margins of the Labrador Sea: a review, in Wilson, R.C.L., Whitmarsh, R.B., Taylor, B., and Froitzheim, N., eds., Non-Volcanic Rifting of Continental Margins: A Comparison of Evidence from Land and Sea: Geological Society, London, Special Publications, v. 187, p. 77-105, https://doi.org/10.1144/ GSL.SP.2001.187.01.05.

Chalmers, J.A., Pulvertaft, T., Christiansen, F.G., Larsen, H.C., Laursen, K.H., and Ottesen, T.G., 1993, The southern West Greenland continental margin: rifting history, basin development, and petroleum potential: Geological Society, London, Petroleum Geology Conference series, v. 4, p. 915-931, https://doi.org/ 10.1144/0040915.

Chalmers, J.A., Larsen, L.M., and Pedersen, A.K., 1995, Widespread Palaeocene volcanism around the northern North Atlantic and Labrador Sea: evidence for a large, hot, early plume head: Journal of the Geological Society, v. 152, p. 965969, https://doi.org/10.1144/GSL.JGS.1995.152.01.14.

Chian, D., Louden, K.E., and Reid, I., 1995, Crustal structure of the Labrador Sea conjugate margin and implications for the formation of nonvolcanic continental margins: Journal of Geophysical Research, v. 100, p. 24239-24253, https://doi.org/10.1029/95JB02162.

Clarke, D.B., and Upton, B.G.J., 1971, Tertiary basalts of Baffin Island: Field relations and tectonic setting: Canadian Journal of Earth Sciences, v. 8, p. 248-258, https://doi.org/10.1139/e71-025.

Connelly, J.N., and Mengel, F.C., 2000, Evolution of Archean components in the Paleoproterozoic Nagssugtoqidian orogen, West Greenland: Geological Society of America Bulletin, v. 112, p. 747-763, https://doi.org/10.1130/00167606(2000)112<747:EOACIT>2.0.CO;2.

Courtillot, V., Jaupart, C., Manighetti, I., Tapponnier, P., and Besse, J., 1999, On causal links between flood basalts and continental breakup: Earth and Planetary Science Letters, v. 166, p. 177-195, https://doi.org/10.1016/S0012 $821 \mathrm{X}(98) 00282-9$

Creason, C.G., 2015, Phanerozoic Exhumation History of Hall Peninsula, Baffin Island: Insights from Apatite and Zircon (U-Th-Sm)/He Thermochronology and 3D Thermokinematic Modeling: Unpublished MSc thesis, Dalhousie University, Halifax, NS, 141 p.

Dale, C.W., Pearson, D.G., Starkey, N.A., Stuart, F.M., Ellam, R.M., Larsen, L.M., Fitton, J.G., and Macpherson, C.G., 2009, Osmium isotopes in Baffin Island and West Greenland picrites: Implications for the ${ }^{187} \mathrm{Os} /{ }^{188} \mathrm{Os}$ composition of the convecting mantle and the nature of high ${ }^{3} \mathrm{He} /{ }^{4} \mathrm{He}$ mantle: Earth and Planetary Science Letters, v. 278, p. 267-277, https://doi.org/10.1016/ j.epsl.2008.12.014.

Dalhoff, F., Larsen, L.M., Ineson, J.R., Stouge, S., Bojesen-Koefoed, J.A., Lassen, S., Kuijpers, A., Rasmussen, J.A., and Nøhr-Hansen, H., 2006, Continental crust in the Davis Strait: new evidence from seabed sampling: Geological Survey of Denmark and Greenland Bulletin, v. 10, p. 33-36.

Dam, G., Larsen, M., and Sønderholm, M., 1998, Sedimentary response to mantle plumes: Implications from Paleocene onshore successions, West and East Greenland: Geology, v. 26, p. 207-210, https://doi.org/10.1130/0091 7613(1998)026<0207:SRTMPI>2.3.CO;2

Deemer, S., Hurich, C., and Hall, J., 2010, Post-rift flood-basalt-like volcanism on the Newfoundland Basin nonvolcanic margin: The $U$ event mapped with spectral decomposition: Tectonophysics, v. 494, p. 1-16, https://doi.org/10.1016/ j.tecto.2010.07.019.

Delescluse, M., Funck, T., Dehler, S.A., Louden, K.E., and Watremez, L., 2015, The oceanic crustal structure at the extinct, slow to ultraslow Labrador Sea spreading center: Journal of Geophysical Research, v. 120, p. 5249-5272, https://doi.org/10.1002/2014JB011739.

Doré, A.G., Lundin, E.R., Fichler, C., and Olesen, O., 1997, Patterns of basement structure and reactivation along the NE Atlantic margin: Journal of the Geo- logical Society, v. 154, p. 85-92, https://doi.org/10.1144/gsigs.154.1.0085.

Eddy, M.P., Jagoutz, O., and Ibañez-Mejia, M., 2017, Timing of initial seafloor spreading in the Newfoundland-Iberia rift: Geology, v. 45, p. 527-530, https://doi.org/10.1130/G38766.1.

Elliott, G.M., and Parson, L.M., 2008, Influence of margin segmentation upon the break-up of the Hatton Bank rifted margin, NE Atlantic: Tectonophysics, v. 457, p. 161-176, https://doi.org/10.1016/j.tecto.2008.06.008.

Engström, J., and Klint, K.E.S., 2014, Continental collision structures and post-orogenic geological history of the Kangerlussuaq area in the southern part of the Nagssugtoqidian Orogen, central West Greenland: Geosciences, v. 4, p. 316334, https://doi.org/10.3390/geosciences4040316.

Forsyth, D.A., Morel-A-L'Huissier, P., Asudeh, I., and Green, A.G., 1986, Alpha Ridge and Iceland-products of the same plume?: Journal of Geodynamics, v. 6, p. 197-214, https://doi.org/10.1016/0264-3707(86)90039-6.

Foulger, G.R., 2002, Plumes, or plate tectonic processes?: Astronomy \& Geophysics, v. 43, p. 6.19-6.23, https://doi.org/10.1046/j.1468-4004.2002.43619.x.

Foulger, G.R., Panza, G.F., Artemieva, I.M., Bastow, I.D., Cammarano, F., Evans, J.R., Hamilton, W.B., Julian, B.R., Lustrino, M., Thybo, H., and Yanovskaya, T.B., 2013, Caveats on tomographic images: Terra Nova, v. 25, p. 259-281, https://doi.org/10.1111/ter.12041.

Foulger, G.R., Christiansen, R.L., and Anderson, D.L., 2015, The Yellowstone "hot spot" track results from migrating basin-range extension, in Foulger, G.R., Lustrino, M., and King, S.D., eds., The Interdisciplinary Earth: A Volume in Honor of Don L. Anderson: Geological Society of America Special Papers, v. 514, p. SPE514-14, https://doi.org/10.1130/2015.2514(14).

Franke, D., 2013, Rifting, lithosphere breakup and volcanism: Comparison of magma-poor and volcanic rifted margins: Marine and Petroleum Geology, v. 43, p. 63-87, https://doi.org/10.1016/j.marpetgeo.2012.11.003.

Franke, D., Neben, S., Ladage, S., Schreckenberger, B., and Hinz, K., 2007, Margin segmentation and volcano-tectonic architecture along the volcanic margin off Argentina/Uruguay, South Atlantic: Marine Geology, v. 244, p. 46-67, https://doi.org/10.1016/j.margeo.2007.06.009.

Funck, T., and Louden, K.E., 1999, Wide-angle seismic transect across the Torngat Orogen, northern Labrador: Evidence for a Proterozoic crustal root: Journal of Geophysical Research, v. 104, p. 7463-7480, https://doi.org/10.1029/ 1999JB900010.

Funck, T., Louden, K.E., Wardle, R.J., Hall, J., Hobro, J.W., Salisbury, M.H., and Muzzatti, A.M., 2000, Three-dimensional structure of the Torngat Orogen (NE Canada) from active seismic tomography: Journal of Geophysical Research, v. 105, p. 23403-23420, https://doi.org/10.1029/2000JB900228.

Funck, T., Jackson, H.R., Louden, K.E., and Klingelhöfer, F., 2007, Seismic study of the transform-rifted margin in Davis Strait between Baffin Island (Canada) and Greenland: What happens when a plume meets a transform: Journal of Geophysical Research, v. 112, p. B04402, https://doi.org/10.1029/2006JB004308.

Funck, T., Gohl, K., Damm, V., and Heyde, I., 2012, Tectonic evolution of southern Baffin Bay and Davis Strait: Results from a seismic refraction transect between Canada and Greenland: Journal of Geophysical Research, v. 117, p. B04107, https://doi.org/10.1029/2011JB009110.

Geoffroy, L., 2005, Volcanic passive margins: Comptes Rendus Geoscience, v. 337, p. 1395-1408, https://doi.org/10.1016/j.crte.2005.10.006.

Geoffroy, L., Callot, J.-P., Scaillet, S., Skuce, A., Gélard, J.P., Ravilly, M., Angelier, J., Bonin, B., Cayet, C., Perrot, K., and Lepvrier, C., 2001, Southeast Baffin volcanic margin and the North American-Greenland plate separation: Tectonics, $v$ 20, p. 566-584, https://doi.org/10.1029/2001TC900003.

Geoffroy, L., Burov, E.B., and Werner, P., 2015, Volcanic passive margins: another way to break up continents: Scientific Reports, v. 5, 14828, https://doi.org/ 10.1038/srep14828

Gerlings, J., Funck, T., Jackson, H.R., Louden, K.E., and Klingelhöfer, F., 2009, Seismic evidence for plume-derived volcanism during formation of the continental margin in southern Davis Strait and northern Labrador Sea: Geophysical Journal International, v. 176, p. 980-994, https://doi.org/10.1111/j.1365246X.2008.04021.x.

Gernigon, L., Blischke, A., Nasuti, A., and Sand, M., 2015, Conjugate volcanic rifted margins, seafloor spreading, and microcontinent: Insights from new high-resolution aeromagnetic surveys in the Norway Basin: Tectonics, p. 907-933, https://doi.org/10.1002/2014TC003717.

Ghods, A., 2002, Is small scale convection responsible for the formation of thick igneous crust along volcanic passive margins?: Geophysical Research Letters, v. 29, p. 3-1-3-4, https://doi.org/10.1029/2001GL014408.

Gill, R.C.O., Pedersen, A.K., and Larsen, J.G., 1992, Tertiary picrites in West Greenland: melting at the periphery of a plume?, in Storey, B.C., Alabaster, T., and Pankhurst, R.J., eds., Magmatism and the Causes of Continental Break-up: Geological Society, London, Special Publications, v. 68, p. 335-348, 
https://doi.org/10.1144/GSL.SP.1992.068.01.21.

Graham, D.W., Larsen, L.M., Hanan, B.B., Storey, M., Pedersen, A.K., and Lupton, J.E., 1998, Helium isotope composition of the early Iceland mantle plume inferred from the Tertiary picrites of West Greenland: Earth and Planetary Science Letters, v. 160, p. 241-255, https://doi.org/10.1016/S0012821X $(98) 00083-1$.

Graham, D.W., Johnson, K.T.M., Priebe, L.D., and Lupton, J.E., 1999, Hotspot-ridge interaction along the Southeast Indian Ridge near Amsterdam and St. Paul islands: Helium isotope evidence: Earth and Planetary Science Letters, v. 167, p. 297-310, https://doi.org/10.1016/S0012-821X(99)00030-8.

Gregersen, U., and Bidstrup, T., 2008, Structures and hydrocarbon prospectivity in the northern Davis Strait area, offshore West Greenland: Petroleum Geoscience, v. 14, p. 151-166, https://doi.org/10.1144/1354-079308-752.

Grist, A.M., and Zentilli, M., 2005, The thermal history of the Nares Strait, Kane Basin, and Smith Sound region in Canada and Greenland: constraints from apatite fission-track and (U-Th-Sm)/He dating: Canadian Journal of Earth Sciences, v. 42, p. 1547-1569, https://doi.org/10.1139/e05-058.

Hansen, K., Dawes, P.R., Frisch, T., and Jensen, P.K., 2011, A fission track transect across Nares Strait (Canada-Greenland): further evidence that the Wegener Fault is a myth: Canadian Journal of Earth Sciences, v. 48, p. 819-840, https://doi.org/10.1139/e10-103.

Hekinian, R., Stoffers, P., Ackermand, D., Révillon, S., Maia, M., and Bohn, M., 1999 Ridge-hotspot interaction: The Pacific-Antarctic Ridge and the foundation seamounts: Marine Geology, v. 160, p. 199-223, https://doi.org/10.1016/ S0025-3227(99)00027-4.

Heron, P.J., and Lowman, J.P., 2011, The effects of supercontinent size and thermal insulation on the formation of mantle plumes: Tectonophysics, v. 510, p. 28 38, https://doi.org/10.1016/j.tecto.2011.07.002

Holm, P.M., Gill, R.C.O., Pedersen, A.K., Larsen, J.G., Hald, N., Nielsen, T.F.D., and Thirlwall, M.F., 1993, The Tertiary picrites of West Greenland: contributions from 'Icelandic' and other sources: Earth and Planetary Science Letters, v. 115, p. 227-244, https://doi.org/10.1016/0012-821X(93)90224-W.

Hosseinpour, M., Müller, R.D., Williams, S.E., and Whittaker, J.M., 2013, Full-fit reconstruction of the Labrador Sea and Baffin Bay: Solid Earth, v. 4, p. 461479, https://doi.org/10.5194/se-4-461-2013.

Hwang, Y.K., Ritsema, J., van Keken, P.E., Goes, S., and Styles, E., 2011, Wavefront healing renders deep plumes seismically invisible: Geophysical Journal International, v. 187, p. 273-277, https://doi.org/10.1111/j.1365-246X.2011.05173.x.

Jackson, H.R., Keen, C.E., Falconer, R.K.H., and Appleton, K.P., 1979, New geophysical evidence for sea-floor spreading in central Baffin Bay: Canadian Journal of Earth Sciences, v. 16, p. 2122-2135, https://doi.org/10.1139/e79-200.

Japsen, P., Bonow, J.M., Green, P.F., Chalmers, J.A., and Lidmar-Bergström, K., 2006 , Elevated, passive continental margins: Long-term highs or Neogene uplifts? New evidence from West Greenland: Earth and Planetary Science Letters, v. 248, p. 330-339, https://doi.org/10.1016/j.epsl.2006.05.036.

Keen, C.E., Dickie, K., and Dehler, S.A., 2012, The volcanic margins of the northern Labrador Sea: Insights to the rifting process: Tectonics, v. 31, TC1011, https://doi.org/10.1029/2011TC002985.

Kerr, A., Hall, J., Wardle, R.J., Gower, C.F., and Ryan, B., 1997, New reflections on the structure and evolution of the Makkovikian-Ketilidian Orogen in Labrador and southern Greenland: Tectonics, v. 16, p. 942-965, https://doi.org/ 10.1029/97TC02286.

Kerr, J.W., 1967, A submerged continental remnant beneath the Labrador Sea: Earth and Planetary Science Letters, v. 2, p. 283-289, https://doi.org/10.1016/0012$821 X(67) 90143-4$.

King, A.F., and McMillan, N.J., 1975, A mid-Mesozoic breccia from the coast of Labrador: Canadian Journal of Earth Sciences, v. 12, p. 44-51, https://doi.org/ $10.1139 / \mathrm{e} 75-005$

Kolb, J., 2014, Structure of the Palaeoproterozoic Nagssugtoqidian Orogen, SouthEast Greenland: Model for the tectonic evolution: Precambrian Research, v. 255, p. 809-822, https://doi.org/10.1016/j.precamres.2013.12.015.

Koopmann, H., Brune, S., Franke, D., and Breuer, S., 2014, Linking rift propagation barriers to excess magmatism at volcanic rifted margins: Geology, v. 42, p. 1071-1074, https://doi.org/10.1130/G36085.1.

Koopmann, H., Schreckenberger, B., Franke, D., Becker, K., and Schnabel, M., 2016, The late rifting phase and continental break-up of the southern South Atlantic: the mode and timing of volcanic rifting and formation of earliest oceanic crust, in Wright, T.J., Ayele, A., Ferguson, D.J., Kidane, T., and Vye-Brown, C., eds, Magmatic Rifting and Active Volcanism: Geological Society, London, Special Publications, v. 420, p. 315-340, https://doi.org/10.1144/SP420.2.

Larsen, H.C., and Saunders, A.D., 1998, Tectonism and volcanism at the southeast Greenland rifted margin: a record of plume impact and later continental rupture: Proceedings of the Ocean Drilling Program, Scientific Results, v. 152, p.
503-534, https://doi.org/10.2973/odp.proc.sr.152.1998.

Larsen, L.M., Pedersen, A.K., Pedersen, G.K., and Piasecki, S., 1992, Timing and duration of Early Tertiary volcanism in the North Atlantic: new evidence from West Greenland, in Storey, B.C., Alabaster, T., and Pankhurst, R.J., eds., Magmatism and the Causes of Continental Break-up: Geological Society, London, Special Publications, v. 68, p. 321-333, https://doi.org/10.1144/ GSL.SP.1992.068.01.20.

Larsen, L.M., Heaman, L.M., Creaser, R.A., Duncan, R.A., Frei, R., and Hutchison, M., 2009, Tectonomagmatic events during stretching and basin formation in the Labrador Sea and the Davis Strait: evidence from age and composition of Mesozoic to Palaeogene dyke swarms in West Greenland: Journal of the Geological Society, v. 166, p. 999-1012, https://doi.org/10.1144/0016-76492009038 .

Larsen, L.M., Pedersen, A.K., Tegner, C., Duncan, R.A., Hald, N., and Larsen, J.G., 2016, Age of Tertiary volcanic rocks on the West Greenland continental margin: volcanic evolution and event correlation to other parts of the North Atlantic Igneous Province: Geological Magazine, v. 153, p. 487-511, https://doi.org/10.1017/S0016756815000515.

Laske, G., Masters, G., Ma, Z., and Pasyanos, M.E., 2012, CRUST1.0: An updated global model of Earth's crust (Abstract): Geophysical Research Abstracts, v. 14, EGU2012-3743-1. Available at: http://igppweb.ucsd.edu/ gabi/crust1.html.

Lawver, L.A., and Müller, R.D., 1994, Iceland hotspot track: Geology, v. 22, p. 311314, https://doi.org/10.1130/0091-7613(1994)022<0311:IHT>2.3.CO;2.

Lawver, L.A., Grantz, A., and Gahagan, L.M., 2002, Plate kinematic evolution of the present Arctic region since the Ordovician, in Miller, E.L., Grantz, A., and Klemperer, S.L., eds., Tectonic Evolution of the Bering Shelf-Chukchi Sea-Arctic Margin and Adjacent Landmasses: Geological Society of America, Special Papers, v. 360, p. 333-358, https://doi.org/10.1130/0-8137-2360-4.333.

Lebedev, S., Schaeffer, A.J., Fullea, J., and Pease, V., 2017, Seismic tomography of the Arctic region: inferences for the thermal structure and evolution of the lithosphere, in Pease, V., and Coakley, B., eds., Circum-Arctic Lithosphere Evolution: Geological Society, London, Special Publications, v. 460, First published online July 6, 2017, https://doi.org/10.1144/SP460.10.

Lenardic, A., Moresi, L.-N., Jellinek, A.M., and Manga, M., 2005, Continental insulation, mantle cooling, and the surface area of oceans and continents: Earth and Planetary Science Letters, v. 234, p. 317-333, https://doi.org/10.1016/ j.epsl.2005.01.038.

Lenardic, A., Moresi, L., Jellinek, A.M., O’Neill, C.J., Cooper, C.M., and Lee, C.T., 2011, Continents, supercontinents, mantle thermal mixing, and mantle thermal isolation: Theory, numerical simulations, and laboratory experiments: Geochemistry, Geophysics, Geosystems, v. 12, Q10016, https://doi.org/10.1029/ 2011GC003663.

Lustrino, M., and Anderson, D.L., 2015, The mantle isotopic printer. Basic mantle plume geochemistry for seismologists and geodynamicists, in Foulger, G.R., Lustrino, M., and King, S.D., eds., The Interdisciplinary Earth: A Volume in Honor of Don L. Anderson: The Geological Society of America, Special Papers, v. 514, p. 257-279, https://doi.org/10.1130/2015.2514(16).

McGregor, E.D., Nielsen, S.B., Stephenson, R.A., Petersen, K.D., and MacDonald, D.I.M., 2013, Long-term exhumation of a Palaeoproterozoic orogen and the role of pre-existing heterogeneous thermal crustal properties: a fission-track study of SE Baffin Island: Journal of the Geological Society, v. 170, p. 877-891, https://doi.org/10.1144/jgs2012-146.

McGregor, E.D., Nielsen, S.B., and Stephenson, R.A., 2014, Basin evolution in the Davis Strait area (West Greenland and conjugate East Baffin/Labrador passive margins) from thermostratigraphic and subsidence modelling of well data: Implications for tectonic evolution and petroleum systems: Bulletin of Canadian Petroleum Geology, v. 62, p. 311-329, https://doi.org/10.2113/gscpgbull. 62.4.311.

McKenzie, D., 1978, Some remarks on the development of sedimentary basins: Earth and Planetary Science Letters, v. 40, p. 25-32, https://doi.org/10.1016/ 0012-821X(78)90071-7.

Mjelde, R., Kvarven, T., Faleide, J.I., and Thybo, H., 2016, Lower crustal high-velocity bodies along North Atlantic passive margins, and their link to Caledonian suture zone eclogites and Early Cenozoic magmatism: Tectonophysics, v. 670 p. 16-29, https://doi.org/10.1016/j.tecto.2015.11.021.

Morgan, W.J., 1971, Convection plumes in the lower mantle: Nature, v. 230, p. 42 43, https://doi.org/10.1038/230042a0.

Mutter, J.C., 1985, Seaward dipping reflectors and the continent-ocean boundary at passive continental margins: Tectonophysics, v. 114, p. 117-131, https://doi.org/10.1016/0040-1951(85)90009-5.

Nielsen, S.B., Stephenson, R., and Thomsen, E., 2007, Dynamics of Mid-Palaeocene North Atlantic rifting linked with European intra-plate deformations: Nature, v. 450, p. 1071-1074, https://doi.org/10.1038/nature06379. 
Nielsen, T.K., Larsen, H.C., and Hopper, J.R., 2002, Contrasting rifted margin styles south of Greenland: Implications for mantle plume dynamics: Earth and Planetary Science Letters, v. 200, p. 271-286, https://doi.org/10.1016/S0012 $821 \mathrm{X}(02) 00616-7$.

Oakey, G.N., and Chalmers, J.A., 2012, A new model for the Paleogene motion of Greenland relative to North America: Plate reconstructions of the Davis Strait and Nares Strait regions between Canada and Greenland: Journal of Geophysical Research: v. 117, B10401, https://doi.org/10.1029/2011JB008942.

Park, I., Clarke, D.B., Johnson, J., and Keen, M.J., 1971, Seaward extension of the west greenland tertiary volcanic province: Earth and Planetary Science Letters, v. 10, p. 235-238, https://doi.org/10.1016/0012-821X(71)90011-2.

Paton, D.A., Pindell, J., McDermott, K., Bellingham, P., and Horn, B., 2017, Evolution of seaward-dipping reflectors at the onset of oceanic crust formation at volcanic passive margins: Insights from the South Atlantic: Geology, v. 45, p. 439-442, https://doi.org/10.1130/G38706.1.

Peace, A., McCaffrey, K., Imber, J., Hobbs, R., van Hunen, J., Foulger, G., and Gerdes, K., 2014, Formation of the West Greenland volcanic margin: Exploring alternatives to the plume hypothesis: $4^{\text {th }}$ Atlantic Conjugate Margins Conference, St. John's, NL, p. 161-162, https://doi.org/10.13140/RG.2.1.4727.1925.

Peace, A., McCaffrey, K., Imber, J., Phethean, J., Nowell, G., Gerdes, K., and Dempsey, E., 2016, An evaluation of Mesozoic rift-related magmatism on the margins of the Labrador Sea: Implications for rifting and passive margin asymmetry: Geosphere, v. 12, p. 1701-1724, https://doi.org/10.1130/GES01341.1.

Peace, A., McCaffrey, K., Imber, J., Hobbs, R., van Hunen, J., and Gerdes, K., 2017a, Quantifying the influence of sill intrusion on the thermal evolution of organic-rich sedimentary rocks in non-volcanic passive margins: An example from ODP 210-1276, offshore Newfoundland, Canada: Basin Research, v. 29, p. 249265, https://doi.org/10.1111/bre.12131

Peace, A., McCaffrey, K., Imber, J., van Hunen, J., Hobbs, R., and Wilson, R., 2017b, The role of pre-existing structures during rifting, continental breakup and transform system development, offshore West Greenland: Basin Research, https://doi.org/10.1111/bre.12257.

Petersen, K.D., and Schiffer, C., 2016, Wilson cycle passive margins: Control of orogenic inheritance on continental breakup: Gondwana Research, v. 39, p. 131144, https://doi.org/10.1016/j.gr.2016.06.012

Redfield, T.F., 2010, On apatite fission track dating and the Tertiary evolution of West Greenland topography: Journal of the Geological Society, v. 167, p. 261271, https://doi.org/10.1144/0016-76492009-036.

Roest, W.R., and Srivastava, S.P., 1989, Sea-floor spreading in the Labrador Sea: A new reconstruction: Geology, v. 17, p. 1000-1003, https://doi.org/10.1130/ 0091-7613(1989)017<1000:SFSITL>2.3.CO;2.

Schaeffer, A., and Lebedev, S., 2015, Seismic tomography of the Arctic lithosphere and asthenosphere (Abstract): Geophysical Research Abstracts, v. 17, p. 2819.

Schiffer, C., Jacobsen, B.H., Balling, N., Ebbing, J., and Nielsen, S.B., 2015a, The East Greenland Caledonides - teleseismic signature, gravity and isostasy: Geophysical Journal International, v. 203, p. 1400-1418, https://doi.org/10.1093/ gji/ggv373.

Schiffer, C., Stephenson, R.A., Petersen, K.D., Nielsen, S.B., Jacobsen, B.H., Balling, N., and Macdonald, D.I.M., 2015b, A sub-crustal piercing point for North Atlantic reconstructions and tectonic implications: Geology, v. 43, p. 1087 1090, https://doi.org/10.1130/G37245.1.

Schiffer, C., Tegner, C., Schaeffer, A.J., Pease, V., and Nielsen, S.B., 2017, High Arctic geopotential stress field and implications for geodynamic evolution, in Pease, V., and Coakley, B., eds., Circum-Arctic Lithosphere Evolution: Geological Society, London, Special Publications, v. 460, First published online April 13, 2017, https://doi.org/10.1144/SP460.6.

Schiffer, C., Peace, A., Phethean, J., Gernigon, L., McCaffrey, K.J.W., Petersen, K.D., and Foulger, G.R., in press, The Jan Mayen Microplate Complex and the Wilson Cycle: in Tectonic Evolution: 50 Years of the Wilson Cycle Concept: Geological Society, London, Special Publications.

Sengör, A.M.C., and Burke, K., 1978, Relative timing of rifting and volcanism on Earth and its tectonic implications: Geophysical Research Letters, v. 5, p. 419 421, https://doi.org/10.1029/GL005i006p00419.

Shellnutt, J.G., Dostal, J., and Yeh, M.-W., 2017, Mantle source heterogeneity of the Early Jurassic basalt of eastern North America: International Journal of Earth Sciences, p. 1-26, https://doi.org/10.1007/s00531-017-1519-0.

Shorttle, O., Maclennan, J., and Lambart, S., 2014, Quantifying lithological variability in the mantle: Earth and Planetary Science Letters, v. 395, p. 24-40, https://doi.org/10.1016/j.epsl.2014.03.040.

Simon, K., Huismans, R.S., and Beaumont, C., 2009, Dynamical modelling of lithospheric extension and small-scale convection: Implications for magmatism during the formation of volcanic rifted margins: Geophysical Journal International, v. 176, p. 327-350, https://doi.org/10.1111/j.1365-246X.2008.03891.x.
Skaarup, N., Jackson, H.R., and Oakey, G., 2006, Margin segmentation of Baffin Bay/Davis Strait, eastern Canada based on seismic reflection and potential field data: Marine and Petroleum Geology, v. 23, p. 127-144, https://doi.org/ 10.1016/j.marpetgeo.2005.06.002.

Skogseid, J., 2001, Volcanic margins: Geodynamic and exploration aspects: Marine and Petroleum Geology, v. 18, p. 457-461, https://doi.org/10.1016/S0264 8172(00)00070-2.

Srivastava, S.P., 1978, Evolution of the Labrador Sea and its bearing on the early evolution of the North Atlantic: Geophysical Journal International, v. 52, p. 313-357, https://doi.org/10.1111/j.1365-246X.1978.tb04235.x.

Srivastava, S.P., and Keen, C.E., 1995, A deep seismic reflection profile across the extinct Mid-Labrador Sea spreading center: Tectonics, v. 14, p. 372-389, https://doi.org/10.1029/94TC02453.

Srivastava, S.P., and Roest, W.R., 1999, Extent of oceanic crust in the Labrador Sea: Marine and Petroleum Geology, v. 16, p. 65-84, https://doi.org/10.1016/ S0264-8172(98)00041-5.

Storey, M., Duncan, R.A., Pedersen, A.K., Larsen, L.M., and Larsen, H.C., 1998, ${ }^{40} \mathrm{Ar} /{ }^{39} \mathrm{Ar}$ geochronology of the West Greenland Tertiary volcanic province: Earth and Planetary Science Letters, v. 160, p. 569-586, https://doi.org/ 10.1016/S0012-821X(98)00112-5.

Suckro, S.K., Gohl, K., Funck, T., Heyde, I., Ehrhardt, A., Schreckenberger, B., Gerlings, J., Damm, V., and Jokat, W., 2012, The crustal structure of southern Baffin Bay: Implications from a seismic refraction experiment: Geophysical Journal International, v. 190, p. 37-58, https://doi.org/10.1111/j.1365 246X.2012.05477.x.

Suckro, S.K., Gohl, K., Funck, T., Heyde, I., Schreckenberger, B., Gerlings, J., and Damm, V., 2013, The Davis Strait crust-a transform margin between two oceanic basins: Geophysical Journal International, v. 193, p. 78-97, https://doi.org/10.1093/gji/ggs126.

Tappe, S., Foley, S.F., Stracke, A., Romer, R.L., Kjarsgaard, B.A., Heaman, L.M., and Joyce, N., 2007, Craton reactivation on the Labrador Sea margins: ${ }^{40} \mathrm{Ar} /{ }^{39} \mathrm{Ar}$ age and $\mathrm{Sr}-\mathrm{Nd}-\mathrm{Hf}-\mathrm{Pb}$ isotope constraints from alkaline and carbonatite intrusives: Earth and Planetary Science Letters, v. 256, p. 433-454, https://doi.org/ 10.1016/j.epsl.2007.01.036.

Tegner, C., Duncan, R.A., Bernstein, S., Brooks, C.K., Bird, D.K., and Storey, M., $1998,{ }^{40} \mathrm{Ar}-{ }^{39} \mathrm{Ar}$ geochronology of Tertiary mafic intrusions along the East Greenland rifted margin: Relation to flood basalts and the Iceland hotspot track: Earth and Planetary Science Letters, v. 156, p. 75-88, https://doi.org/ 10.1016/S0012-821X(97)00206-9.

Thybo, H., and Artemieva, I.M., 2013, Moho and magmatic underplating in continental lithosphere: Tectonophysics, v. 609, p. 605-619, https://doi.org/ 10.1016/j.tecto.2013.05.032.

Umpleby, D.C., 1979, Geology of the Labrador Shelf: Geological Survey of Canada, Paper 79-13, 41 p., https://doi.org/10.4095/105927.

Upton, B.G.J., 1988, History of Tertiary igneous activity in the N Atlantic borderlands, in Morton, A.C., and Parson, L.M., eds., Early Tertiary Volcanism and the Opening of the NE Atlantic: Geological Society, London, Special Publications, v. 39, p. 429-453, https://doi.org/10.1144/GSL.SP.1988.039.01.38.

Van der Linden, W.J.M., 1975, Crustal attenuation and sea-floor spreading in the Labrador Sea: Earth and Planetary Science Letters, v. 27, p. 409-423, https://doi.org/10.1016/0012-821X(75)90060-6.

van Gool, J.A.M., Connelly, J.N., Marker, M., and Mengel, F.C., 2002, The Nagssugtoqidian Orogen of West Greenland: tectonic evolution and regional correlations from a West Greenland perspective: Canadian Journal of Earth Sciences, v. 39, p. 665-686, https://doi.org/10.1139/e02-027.

van Wijk, J., van Hunen, J., and Goes, S., 2008, Small-scale convection during continental rifting: Evidence from the Rio Grande rift: Geology, v. 36, p. 575-578, https://doi.org/10.1130/G24691A.1.

van Wijk, J.W., Huismans, R.S., ter Voorde, M., and Cloetingh, S.A.P.L., 2001, Melt generation at volcanic continental margins: No need for a mantle plume? Geophysical Research Letters, v. 28, p. 3995-3998, https://doi.org/10.1029/ 2000 GL012848.

Welford, J.K., and Hall, J., 2013, Lithospheric structure of the Labrador Sea from constrained 3-D gravity inversion: Geophysical Journal International, v. 195, p. 767-784, https://doi.org/10.1093/gji/ggt296.

White, R.S., 1992, Magmatism during and after continental break-up, in Storey, B.C., Alabaster, T., and Pankhurst, R.J., eds., Magmatism and the Causes of Continental Break-up: Geological Society, London, Special Publications, v. 68, p. 1-16, https://doi.org/10.1144/GSL.SP.1992.068.01.01.

Whittington, A.G., Hofmeister, A.M., and Nabelek, P.I., 2009, Temperature-dependent thermal diffusivity of the Earth's crust and implications for magmatism: Nature, v. 458, p. 319-321, https://doi.org/10.1038/nature07818.

Wilson, R.C.L., Whitmarsh, R.B., Froitzheim, N., and Taylor, B., 2001, Introduction: 
the land and sea approach, in Wilson, R.C.L., Whitmarsh, R.B., Taylor, B., and Froitzheim, N., eds., Non-Volcanic Rifting of Continental Margins: A Comparison of Evidence from Land and Sea: Geological Society, London, Special Publications, v. 187, p. 1-8, https://doi.org/10.1144/GSL.SP.2001.187.01.01.

Wilson, R.W., Klint, K.E.S., van Gool, J.A.M., McCaffrey, K.J.W., Holdsworth, R.E., and Chalmers, J.A., 2006, Faults and fractures in central West Greenland: onshore expression of continental break-up and sea-floor spreading in the Labrador-Baffin Bay Sea: Geological Survey of Denmark and Greenland Bulletin, v. 11, p. 185-204.

Wilton, D., Burden, E., and Greening, A., 2016, The Ford's Bight Diatreme - a Cretaceous alnöite pipe from the northern Labrador coast and possible onland remnant from the opening of the Labrador Sea: Arctic Technology Conference, St. John's, NL, p. 1-10, https://doi.org/10.4043/27378-MS.

Wilton, D.H.C., Taylor, R.C., Sylvester, P.J., and Penney, G.T., 2002, A review of kimberlitic and ultramafic lamprophyre intrusives from northern Labrador: Newfoundland Department of Mines and Energy Geological Survey, Report 02-1, p. 343-352.

Yaehne, S., 2008, Apatite (U-Th-Sm)/He thermochronology of the eastern Arctic rim; Evolution of the north-central Baffin Island rifted margin: Unpublished BSc thesis, Dalhousie University, Halifax, NS.

Received June 2017

Accepted as revised August 2017

First published on the web August 2017 